\title{
HAK ASASI MANUSIA DI BIDANG SOSIAL DAN BUDAYA
}

\author{
Resty Nurqomah \\ 2010128220014@mhs.ulm.ac.id \\ Program Studi Pendidikan IPS Fakultas Keguruan dan Ilmu Pendidikan \\ Universitas Lambung Mangkurat
}

\begin{abstract}
Abstrak
HAM atau Hak Asasi Manusia merupakan hak yang dasar secara kodrat pasti dimiliki dengan melekat pada diri seorang individu atau manusia. Bersifat secara universal dan pastinya harus dilindungi dengan hukum sehingga tidak dapat dirampas ataupun dikurangi karena, kodratnya haruslah dipertahankan hak tersebut. Di Indonesia pada Bab XA ada Perubahan UndangUndang Dasar tahun 1945 yang menentukan hak asasi manusia. Dengan salah satunya berkaitan pada hak di bidang sosial budaya dengan identifikasinya belum secara jelas dan rinci tetapi masih tersebar pada Pasal Perubahan Undang-Undang Dasar 1945. Permasalahan budaya merupakan seluruh sistem ataupun tata nilai maupun perilaku mental, pola pikir, pola tingkah laku dalam bermacam aspek kehidupan yang tidak memuaskan untuk warga secara totalitas, alias dapat dikatakan kalau permasalahan budaya ialah tata nilai yang bisa memunculkan krisiskrisis kemasyarakatan yang hendak menimbulkan "dehumanisasi" ataupun terjadi pengurungan terhadap seorang. Permasalahan tersebut mencakup bermacam aspek kehidupan yang seluruhnya menggambarkan ungkapan permasalahan kemanusiaan serta budaya.
\end{abstract}

Kata Kunci: Hak asasi manusia, Hak asasi sosial Budaya, Warga negara

\section{Pendahuluan}

Menurut Mariam Budiardjo, HAM merupakan hak-hak yang dipunyai oleh manusia yang sudah diperoleh serta dibawanya bertepatan dengan kelahiran serta kehadirannya dalam hidup warga. Hak ini terdapat pada manusia tanpa membedakan bangsa, ras, agama, kalangan, tipe kelamin, sebab itu bertabiat asasi serta umum. Dasar dari seluruh hak asasi, di mana seluruh orang wajib mendapatkan peluang dalam mengembangkan bakat serta cita-citanya. (Mariam 
Budiardjo, 1982: 120). Serta pada Undang- Undang Republik Indonesia Nomor 39 tahun 1999, Hak asasi manusia merupakan seperangkat hak dasar yang menempel pada hakikat serta padakeberadaan manusia. Selaku makhluk Tuhan Yang Maha Esa serta harus dihormati, dijunjung besar, serta dilindungi oleh negeri, hukum, pemerintah, serta tiap orang demi kehormatan dan proteksi harkat serta martabat manusia. Hak asasi manusia dari bahasa Prancis dituturkan "Droit LHomme", "hak-hak manusia" serta pada bahasa Inggris dituturkan "Human Rights". Bersamaan dengan pertumbuhan ajaran di Negeri Hukum, di mana manusia ataupun warga negera memiliki hak utama serta mendasar yang harus dilindungi oleh Pemerintah.

Sehingga timbul sebutan "Basic Rights" ataupun "Fundamental Rights". Apabila diterjemahkan ke dalam bahasa Indonesia yakni menggambarkan hak-hak dasar manusia ataupun lebih diketahui dengan sebutan "Hak asasi manusia" (Ramdlon Naning, 1982: 97). Penafsiran hak asasi manusia selaku hak-hak bagi hukum memiliki penafsiran yang lebih luas, bukan saja hak-hak alamiah maupun hak moral saja, namun meliputi hak-hak bagi hukum yang terbuat oleh tubuh yang berwenang dalam negeri. Yang diartikan dengan hak dalam pembicaraan dengan menimpa hak asasi manusia sesuai yang dimaksudkan di area kondisi ataupun wilayah kebebasan berperan. Di mana pemerintah tidak mengadakan pembatasannya, sehingga membiarkan kepada orang ataupun perseorangan buat memilah sendiri. Hak asasi manusia pada sosial budaya merupakan hak yang memiliki hubungan dengan adanya kehidupan bermasyarakat yaitu, hak dalam memilih, mendapatkan, juga dalam menentukan pendidikan.

\section{Metode Penelitian}

Dalam pendekatan penataan ini berbentuk kualitatif, artinya data yang dikumpulkan bukan berupa angka melainkan dari buletin ataupun harian dan dokumen resmi yang lain. Taylor dan Bogdan menyebutkan bahwa penataan kualitatif dapat diartikan penataan yang menghasilkan data deskriptif mengenai kata-kata lisan maupun tertulis, dan tingkah laku yang dapat diamati dari orang- orang yang diteliti. Dalam pengumpulan data dan informasi mengenakan penulusuran pustaka dan pencarian sumber- sumber relevan melalui internet, dari media elektronik berupa buletin ataupun harian dan dokumen yang lain. Tata cara pengumpulan data yang dicoba, ialah:

1. Saat sebelum analisis data dilaksanakan, terlebih dahulu dicoba studi pustaka yang jadi bahan pertimbangan dan catatan pengetahuan buat penulis dalam melingkupi kegiatan dan konsep yang tercakup dalam penataan. 
2. Melakukan pembahasan analisis dari data-data yang diperoleh, diperlukan data referensi yang digunakan sebagai acuan, dimana data tersebut dapat dibesarkan buat dapat mencari kesatuan materi sehingga diperoleh suatu kesimpulan.

3. Dikumpulkan dari berbagai referensi, baik jurnal, artikel dan lainnya sehingga akhirnya akan berbentuk tulisan diartikel ini.

\section{Hak Asasi Manusia di bidang Sosial dan Budaya}

Pada hak sosial dan budaya identik dengan Basic Humanities, di mana Humanities dari kata latin "Human", "manusiawi", "berbudaya" serta "berbudi halus" (refined) yang diharap seorang menekuni Basic Humanities bukanlah sama dengan the humanities (pengetahuan budaya) yang menyangkut keterampilan filsafat serta seni dalam seni pahat, seni tari serta lainlain. Dalam seperangkat konsep dasar ilmu sosial budaya dasar secara interdisiplin digunakan selaku perlengkapan bagi pendekatan serta pemecahan permasalahan yang muncul serta tumbuh dalam warga. Dengan demikian ilmu sosial dan budaya dasar membagikan alternative sudut pandang atas pemecahan permasalahan sosial budaya dimasyarakat. Bersumber pada uraian yang diperoleh dari kajian ilmu sosial budaya dasar, mahasiswa dapat mengorientasikan diri buat berikutnya mampu mengenali ke arah mana pemecahan permasalahan harus dicoba. Dalam hak sosial dan budaya mengkaji masalah sosial, kemanusiaan serta budaya, sekalian pula member dasar pendekatan yang bersumber dari dasar-dasar ilmu sosial yang terintegrasi.

Ruang lingkup hak sosial dan budaya memuat masalah, seperti:

1. Pada aspek kehidupan secara keseluruhan dengan mengungkit sebuah ungkapan pada permasalahan manusia dan juga budaya dengan pendekatan menggunakan ilmu pengetahuan budaya (the humanities) baik dari seging keahlian (disiplin) pada pengetahuan budaya ataupun melalui gabungan (antar-bidang) dari beberapa disiplin pengetahuan budaya.

2. Pada hakekat manusia yang universal tapi juga beraneka ragam, di wujudkan dalam masing-masing kebudayaan secara tempat atau waktu.

Hubungannya pada kehidupan sehari-hari, yaitu:

1) Dengan kebiasaan serta minat untuk menyelidiki yang mungkin ada apa yang terjadi di sekitar lingkungan juga di luar lingkungan tersebut.

2) Dengan keberanian moral dalam mempertahankan nilai yang dirasa dapat diterima dengan tanggung jawab, juga sebaliknya dapat menolak nilai yang dirasa tidak benar.

\section{Hak Asasi Manusia di bidang Sosial}


Hak asasi manusia bidang sosial merupakan hak asasi manusia yang berkaitan dengan hak atas jaminan sosial, hak atas perumahan serta hak atas pembelajaran. Dalam Pergantian UUD 1945 ditetapkan:

1. Pasal 28H ayat (3) Perubahan UUD 1945 memastikan: Tiap orang berhak atas jaminan sosial yang membolehkan pengembangan dirinya secara utuh selaku manusia yang bermatabat.

2. Pasal $28 \mathrm{H}$ ayat (1) Pergantian UUD 1945 memastikan: Tiap orang berhak hidup sejahtera lahir serta batin, bertempat tinggal, serta memperoleh area hidup yang baik serta sehat dan berhak mendapatkan pelayanan kesehatan.

3. Pasal 31 Pergantian UUD 1945 memastikan tentang pembelajaran serta kebudayaan ialah:

a. Ayat (1) Tiap masyarakat Negeri berhak mendapatkan pendidikan.

b. Ayat (2) Tiap masyarakat Negeri harus menjalani pembelajaran dasar serta pemerintah harus membiayainya.

c. Ayat (3) Pemerintah mengusahakan serta menyelenggarakan satu system pembelajaran nasional yang dapat meningkatkan keimanan dan ketakwaan dan akhlak mulia dalam rangka mencerdaskan kehidupan bangsa yang diatur dengan Undang- undang.

d. Ayat (4) Negeri memprioritaskan anggaran pembelajaran sekurang-kurangnya $20 \%$ dari anggaran pemasukan serta belanja Negeri serta dari anggaran pemasukan serta belanja wilayah buat penuhi kebutuhan penyelenggaraan pembelajaran nasional.

e. Ayat (5) Pemerintah memajukan ilmu pengetahuan serta teknologi dengan menjunjung besar nilai-nilai agama serta persatuan bangsa buat kemajuan peradaban dan kesejahteraan umat manusia.

\section{Hak Asasi Manusia di bidang Budaya}

Hak asasi manusia dalam bidang budaya bisa diidentifikasi pada:

1. Pasal 28C Pergantian UUD 1945 memastikan kalau: Tiap orang berhak meningkatkan diri lewat pemenuhan kebutuhan dasarnya, berhak menemukan pembelajaran serta mendapatkan arti dari ilmu pengetahuan serta teknologi, seni serta budaya, demi menaikkan mutu hidupnya untuk kesejahteraan umat manusia.

2. Pasal 28I ayat (3) Pergantian UUD 1945 memastikan kalau: Bukti diri budaya serta hak warga tradisional dihormati selaras dengan pertumbuhan era serta peradaban.

3. Pasal 32 Pergantian UUD 1945 memastikan: 
a. Ayat (1) Negeri memajukan kebudayaan nasional Indonesia ditengah peradaban dunia dengan menjamin kebebasan masyarakat dalam memelihara serta meningkatkan nilainilai budayanya.

b. Ayat (2) Negeri menghormati serta memelihara bahasa wilayah selaku kekayaan budaya nasional.

\section{Hak Sosial dan Budaya pada Pendidikan}

Dalam hal pendidikan pada Undang-Undang Republik Indonesia tahun 2003 mengenai Sistem Pendidikan Nasional adalah dasar hukum untuk menyelenggarakan dan mereformasi sistem pendidikan nasional. Di Undang-Undang tersebut memuat adanya visi, misi, tujuan, dan fungsi pada pendidikan secara relevan, bermutu sehingga sesuai dengan yang dibutuhkan masyarakat dengan berdaya saing yang baik pada kehidupan arus globalisasi. Dalam visi pendidikan Indonesia adanya ingin mewujudkan sistem pendidikan pada pranata sosial yang sangatlah kuat serta juga berwibawa untuk tujuannya memberdayakan seluruh masyarakat atau warga negara sehingga dapat berkembang dan tumbuh sebagai manusia yang memiliki kualitas serta produktif pada saat menjawab atau menghadapi tantangan yang selalu berbeda di setiap zamannya di karenakan zaman yang selalu berubah. Di mana tidak akan lagi ada arti mengenal adanya batasan di setiap antar negara baik dari segi ruang ataupun pada segi waktu. Selaku entitas yang terpaut dalam budaya serta peradaban manusia, pembelajaran di bermacam belahan dunia hadapi pergantian sangat mendasar dalam masa globalisasi.

Di masa globalisasi ini sangatlah meningkat perkembangannya, baik pada ilmu pengetahuan dan juga pada teknologi, yang di mana semua itu akan dapat menolong individu atau kelompok baik secara langsung ataupun daring di sekitar antar daerah ataupun antar negara. Dalam masa globalisasi saat ini, pembelajaran telah jadi komoditas yang kian menarik. Pembelajaran dimaksudkan untuk mempersiapkan bangsa menghadapi masa depan serta menjadikan bangsa ini bermartabat di antara bangsa-bangsa lain di dunia. Masa depan yang senantiasa tumbuh akan menuntut pembelajaran dalam membiasakan diri berproses demokrasi serta membangun bangsa. Dalam masa globalisasi, persaingan bakal terus menjadi ketat, sehingga sangat diperlukan kebijakan serta aktivitas secara langsung. Jika kita perhatikan di masa globalisasi diperlukan bentuk dari diri kita, apakah bisa diterima keberadaan di belahan dunia manapun, dengan bekal sertifikat Nasional. Di masa globalisasi ini tidak cukup hanya pada sertifikat Nasional, tetapi kita juga memerlukan sertifikat internasional selaku pengakuan 
atas eksistensi kita di tingkat internasional, sehingga kita bisa berselancar ke negeri manapun dengan sertifikat internasional yang kita miliki.

\section{Simpulan}

Dalam hak sosial dan budaya mengkaji masalah sosial, kemanusiaan serta budaya, sekalian pula member dasar pendekatan yang bersumber dari dasar-dasar ilmu sosial yang terintegrasi. Hak asasi manusia bidang sosial merupakan hak asasi manusia yang berkaitan dengan hak atas jaminan sosial, hak atas perumahan serta hak atas pembelajaran. Dalam hal pendidikan pada Undang-Undang Republik Indonesia tahun 2003 mengenai Sistem Pendidikan Nasional adalah dasar hukum untuk menyelenggarakan dan mereformasi sistem pendidikan nasional. Di Undang-Undang tersebut memuat adanya visi, misi, tujuan, dan fungsi pada pendidikan secara relevan, bermutu sehingga sesuai dengan yang dibutuhkan masyarakat dengan berdaya saing yang baik pada kehidupan arus globalisasi. Di masa globalisasi ini sangatlah meningkat perkembangannya, baik pada ilmu pengetahuan dan juga pada teknologi, yang di mana semua itu akan dapat menolong individu atau kelompok baik secara langsung ataupun daring di sekitar antar daerah ataupun antar negara. Dalam masa globalisasi saat ini, pembelajaran telah jadi komoditas yang kian menarik.

\section{Referensi}

Budiardjo, M. 2019. Dasar-Dasar Ilmu Politik, Edisi revisi. Jakarta: PT Gramedia Pustaka Utama

Firdaos, R. (2015). Orientasi Pedagogik Dan Perubahan Sosial Budaya Terhadap Kemajuan Ilmu Pendidikan Dan Teknologi. Al-Tadzkiyyah: Jurnal Pendidikan Islam, 6(1), 106117.

Manusia, K. N. H. A. (1997). Hak Asasi Manusia. Gramedia Pustaka Utama, Jakarta.

Nasution, M., Daulay, M., Susanti, N., \& Syam, S. (2015). Ilmu sosial budaya dasar.

Putra, M. A. H. (2019). Building Character Education Through The Civilization Nations Children. The Kalimantan Social Studies Journal, 1(1), 12-17.

Subawa, I. M. (2008). Hak Asasi Manusia Bidang Ekonomi Sosial Dan Budaya Menurut Perubahan UUD 1945. Kertha Patrika, 33(1). 
Umanailo, M. C. B., Sos, S., Umanailo, M. C. B., \& Sos, S. (2016). Ilmu sosial budaya dasar. Universitas Islam Indonesia (Yogyakarta). Pusat Studi Hak Asasi Manusia (PUSHAM), Smith, R. K., Asplund, K. D., \& Marzuki, S. (2008). Hukum hak asasi manusia. Pusat Studi Hak Asasi Manusia, Universitas Islam Indonesia (PUSHAM UII). 